\title{
The relationship between sleep disturbance and cognitive impairment in mood disorders: A systematic review
}

Oliver Pearson ${ }^{1,2}$, Nora Uglik-Marucha ${ }^{1}$, Kamilla W. Miskowiak ${ }^{3}$, Scott A. Cairney ${ }^{4,5}$, Ivana Rosenzweig ${ }^{6,7}$, Allan H. Young ${ }^{2,8}$, Paul R.A. Stokes ${ }^{2,8}$

${ }^{1}$ Psychometrics and Measurement Lab, Biostatistics and Health Informatics Department, Institute of Psychiatry, Psychology and Neuroscience, King's College London, SE5 8AF, London, UK

${ }^{2}$ Centre for Affective Disorders, Department of Psychological Medicine, Institute of Psychiatry \& Psychology and Neuroscience, King's College London

${ }^{3}$ Copenhagen Affective Disorder Research Centre (CADIC), Psychiatric Centre Copenhagen, Copenhagen University Hospital, Rigshospitalet, Copenhagen, Denmark.

${ }^{4}$ Department of Psychology, University of York, York, YO10 5DD

${ }^{5}$ York Biomedical Research Institute, University of York, York, YO10 5DD

${ }^{6}$ Sleep and Brain Plasticity Centre, Department of Neuroimaging, IoPPN, KCL

7Sleep Disorders Centre, Guy's and St Thomas' Hospital, GSTT NHS, London

${ }^{8}$ South London and Maudsley NHS Foundation Trust, Bethlem Royal Hospital, Monks Orchard Road, Beckenham, Kent, BR3 3BX, United Kingdom

\section{Corresponding Author:}

Oliver Pearson

Email: oliver.pearson@kcl.ac.uk

Research assistant

Psychometrics and Measurement Lab

Department of Biostatistics and Health Informatics

Institute of Psychiatry, Psychology \& Neuroscience, King's College London, 16 De Crespigny Park, London, SE5 8AF, UK

Abstract word count: 256, Text word count: 3436,

Number of Tables: 2, Number of Figures: 1 


\begin{abstract}
Background: Cognitive impairment experienced by people with bipolar disorders (BD) or major depressive disorder (MDD) is associated with impaired psychosocial function and poorer quality of life. Sleep disturbance is another core symptom of mood disorders which may be associated with, and perhaps worsen, cognitive impairments. The aim of this systematic review was to critically assess the relationship between sleep disturbance and cognitive impairment in mood disorders.

Methods: In this systematic review, relevant studies which examined sleep disturbance and cognitive function in people with mood disorders were identified using electronic database searches of PsychINFO, MEDLINE, Embase and Web of Science. Findings: Fourteen studies were included; eight investigated people with BD, five investigated people with MDD, and one included both people with MDD and people with BD. One study was an intervention for sleep disturbance and the remaining thirteen studies used either a longitudinal or cross-sectional observational design. Ten studies reported a significant association between subjectively measured sleep disturbance and cognitive impairment in people with MDD or BD after adjusting for demographic and clinical covariates, whereas no such association was found in healthy participants. Two studies reported a significant association between objectively measured sleep abnormalities and cognitive impairment in mood disorders. One study of cognitive behavioural therapy for insomnia modified for BD (CBTI-BD) found an association between improvements in sleep and cognitive performance in BD. Interpretation: There is preliminary evidence to suggest a significant association between sleep disturbance and cognitive impairment in mood disorders. These findings suggest that identifying and treating sleep disturbance may be important when addressing cognitive impairment in MDD and BD. Funding: none.
\end{abstract}

Key words: sleep disturbance, sleep disorder, insomnia, hypersomnia, cognitive impairment, bipolar disorder, major depressive disorder 
medRxiv preprint doi: https://doi.org/10.1101/2021.08.12.21261470; this version posted August 13, 2021. The copyright holder for this preprint (which was not certified by peer review) is the author/funder, who has granted medRxiv a license to display the preprint in perpetuity.

All rights reserved. No reuse allowed without permission.

\section{Introduction}

Cognitive impairment in people with bipolar disorders (BD) or major depressive disorder (MDD) is associated with reduced functional capacity, ${ }^{1,2}$ poor illness prognosis, ${ }^{3,4}$ and poor quality of life.,6 Meta-analyses have reported significant deficits in executive function, memory and attention in people with MDD currently experiencing a depressive episode, with effect sizes ranging from $d=-0.32$ to -

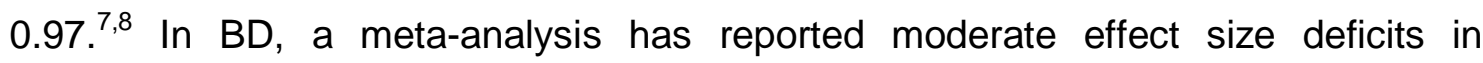
executive function in people experiencing depressive episodes $(d=-0.55)$ and large effect sizes in people experiencing manic episodes $(d=-0.72)^{9}$. However, cognitive impairment is not confined to mood episodes, but persists during euthymia in MDD and BD. For example, Rock et al. $^{7}$ found moderate effect size deficits in executive function and attention in people with remitted MDD, while Semkovska et al. ${ }^{10}$ identified deficits in working memory and long-term memory. In BD, medium to large effect size deficits in executive function, verbal memory, sustained attention and psychomotor speed have been identified by a meta-analysis. ${ }^{11}$ Nevertheless, there is considerable heterogeneity in cognitive impairments across people with mood disorders and approximately $35 \%$ of people with $\mathrm{MDD}^{12}$ and $20-40 \%$ of people with $\mathrm{BD}^{13,14}$ experience moderate to severe impairment in several cognitive domains.

The aetiology of cognitive impairment in mood disorders is not fully understood, ${ }^{15}$ and determining how cognitive impairment is mediated in MDD and BD is a key priority. Sleep disturbance may be one contributing factor. Sleep disturbances are core features of manic episodes, hypomanic episodes and major depressive episodes manifesting as insomnia or hypersomnia and fatigue in major depressive episodes and a decreased need for sleep in manic or hypomanic episodes. ${ }^{16}$ There is also growing evidence to suggest that sleep disturbance persists during euthymia in a substantial proportion of people with mood disorders. Clinically significant sleep disturbances are reported by $70 \%$ of euthymic people with $\mathrm{BD}^{17}$ and $44-60 \%$ of euthymic people with $\mathrm{MDD}^{18-20}$. Moreover, sleep disturbance is associated with higher rates of relapse and suicide attempts in both $\mathrm{BD}^{21}$ and $\mathrm{MDD}^{22}$. Sleep disturbances escalate just before manic and depressive relapse in $\mathrm{BD}$, and worsen during these episodes. ${ }^{23}$ 
There is strong evidence detailing the negative effects of sleep disturbance on many aspects of cognition in healthy individuals ${ }^{24}$, including fragmented memory loss ${ }^{25}$ and impaired suppression of unwanted thoughts ${ }^{26}$. Recently, evidence has emerged to suggest an association between sleep disturbance and cognitive impairment in mood disorders. For example, Bradley et al. ${ }^{27}$ found that people with BD and abnormal sleep patterns, as measured by sleep actigraphy, performed significantly poorer than healthy participants in cognitive performance, whereas people with BD and normal sleep patterns did not significantly differ from healthy participants. As yet, there has not been a systematic review of the relationship between sleep disturbance and cognitive impairment in mood disorders.

The aim of this systematic review was to critically analyse the relationship between sleep disturbance and cognitive impairment in MDD and BD. In particular, the association between sleep disturbance and cognitive impairment, and relevant factors moderating, mediating, and confounding the relationship will be examined.

\section{Methods}

\section{Literature search}

Two reviewers (OP and NUM) independently performed the literature search. Relevant studies were identified using electronic database searches of PsychINFO, MEDLINE, Embase and Web of Science. The following search string was used: [(sleep disturb*) OR (sleep disorder*) OR (insomn*) OR (hypersomn*)] AND [(cognitive impair $\left.\left.{ }^{\star}\right)\right]$ AND [(bipolar $\left.{ }^{\star}\right)$ OR $\left(\right.$ depress $\left.\left.^{*}\right)\right]$. Papers were extracted from inception until February 2021. Only studies written in English were considered. The relevance of the article was initially verified by title and abstract review and then by a further review of each manuscript to verify whether they met the inclusion and exclusion criteria. This systematic review followed PRISMA $2020^{28}$ guidelines, although a study protocol was not registered.

\section{Inclusion and exclusion criteria}

All databases were screened following the same protocol. Included studies were required to include participants with a diagnosis of MDD, BD-I or BD-II, meeting criteria for ICD- $9^{29}$ or subsequent editions, or DSM-III ${ }^{30}$ or subsequent editions. Included studies were required to measure both sleep disturbance and cognition. 
Studies were excluded if they: did not primarily include people with a diagnosis of MDD, BD-I or BD-II; included only participants with dysthymia or cyclothymia or with comorbid neurological disorders (e.g. dementia, epilepsy or stroke) or mild cognitive impairment $(\mathrm{MCl})$; included primarily older participants; were follow-up studies or case reports; were not published by a peer-reviewed scientific journal.

\section{Data extraction}

The following data were extracted: study name and year; participant sample size, age range, disorder and mood state of participants, measures of sleep and cognition, a summary of main findings and study limitations.

\section{Quality assessment}

Two reviewers (OP and NUM) independently assessed the quality of included studies using the Quality Assessment Tool for Quantitative Studies, developed by the Effective Public Health Practice Project (EPHPP). ${ }^{31}$ The following criteria of each study were rated as either strong, moderate or weak: selection bias, design, confounders, blinding, data collection methods, and withdrawals/drop-outs (if applicable). These ratings were aggregated to form a global rating: studies were rated globally as strong if they received no weak ratings; moderate if they received one weak rating; and weak if they received two or more weak ratings.

\section{Results}

A total of 3094 studies were identified, which was reduced to 2208 after duplicates were removed. Following primary assessment of titles and abstracts, this was reduced to 30 studies. Based on secondary assessment of full texts, we included 14 studies that fulfilled the eligibility criteria (please see Figure 1 for further details).

\section{INSERT FIGURE 1 HERE PLEASE}

\section{Studies}

Of the 14 included studies, eight included people with $\mathrm{BD}^{27,32-37}$, five included people with $\mathrm{MDD}^{38-42}$, and one included both people with MDD and people with BD $^{43}$ (see Table 1). These studies were published between years 2012-2020. A total of 2353 people with mood disorders were included in these studies, 1083 people with MDD 
and 1270 people with BD. The mood state of participants varied across studies. Of the eight BD studies, six included only euthymic participants ${ }^{32,33,35,35,37,44}$, whereas two included participants in any mood state. ${ }^{27,34}$ Of the five MDD studies, four only included people currently experiencing a depressive episode; however, Wilckens et al. included both people with current depression and people with remitted depression. Mood state was not described in the one study of people with MDD or $\mathrm{BD}^{43}$.

\section{INSERT TABLE 1 HERE PLEASE}

\section{$B D$ results}

Six of the eight BD studies reported associations between sleep disturbance and cognitive impairment. Kanady et al. ${ }^{33}$ found that greater sleep time variability predicted poorer working memory $(p<0.01)$ and verbal learning performance $(p<$ 0.01 ) in BD. Furthermore, following treatment with cognitive behaviour therapy for insomnia modified for bipolar disorder $\left(\mathrm{CBTI}-\mathrm{BD}^{45}\right)$, a reduction in total wake time predicted improved working memory $(p<0.05)$ and a reduction in sleep time variability predicted improved verbal learning $(p<0.05)$. Laskemoen et al. ${ }^{34}$ found significant associations between insomnia and processing speed $(p<0.001)$, insomnia and inhibition ( $p<0.01$ ), hypersomnia and processing speed $(p<0.01)$, and hypersomnia and inhibition $(p<0.05)$ in people with BD, whereas no association between sleep disturbances and cognition was found in healthy participants. Samalin $^{35}$ et al. found that sleep disturbances were indirectly associated with cognitive function potentially mediated via residual depressive symptoms and perceived cognitive performance $(p=0.001)$. Another study by Samalin et al. $^{46}$ reported that participants with impaired cognitive functioning had significantly higher scores $(p<0.02)$, and thus more severe sleep disruptions, on PSQI than participants with satisfactory cognitive functioning. Volkert et al. ${ }^{37}$ reported that people with BD experiencing persistent sleep disturbances show more severe cognitive dysfunctions $(p<0.05)$. Bradley et al. ${ }^{27}$ found that people with BD with normal sleep patterns were not significantly different to healthy participants in cognitive functions, but people with $\mathrm{BD}$ and sleep disturbance (including objective measures) performed significantly worse in cognitive tests than healthy participants $(p<0.001)$. Russo et al. ${ }^{44}$ found that sleep disturbance was significantly negatively associated with social cognition ( $r$ 
$=-0.273, p=0.004)$, but only associated at a trend level with working memory $(r=$ $-0.179, p=0.061)$ and visual learning $(r=-0.161, p=0.094)$. Boland et $a^{32}$ reported no significant associations between sleep disturbance (including objective measures) and cognition, except for a significant negative correlation between daytime dysfunction due to sleep disturbance and working memory $(r=-0.57, p=$ 0.03).

\section{MDD results}

In MDD, Cabanel et al. ${ }^{38}$ reported that patients with severely impaired sleep quality (PSQI > 10) had significantly poorer performance on the TMT-A (visuomotor processing speed; $p=0.011$ ) and the TMT-B (executive function; $p=0.015$ ) than people with MDD with normal or moderately impaired sleep quality (PSQI < 10). Cha et al. $^{41}$ found that sleep quality predicted impairments in subjective cognitive performance $(p<0.001)$ and objective cognitive impairments $(p=0.017)$. Depression severity was a partial mediator of the relationship between subjective cognitive function and sleep quality $(B=-0.43 ; 95 \% \mathrm{Cl},-0.56,-0.33 ; B=-0.18 ; 95 \%$ $\mathrm{Cl},-0.30,-0.07$ after controlling for depression severity). Wilckens et al. ${ }^{42}$ reported that higher wake after sleep onset (i.e., longer periods of wakefulness occurring after defined sleep onset), and shorter total sleep time, were linearly associated with slower response time across single-task $(p=0.10)$ and switching blocks $(p=0.005)$ considered a proxy for condition-independent psychomotor slowing ${ }^{47}$; however, these associations were also observed in healthy controls and therefore not specific to MDD. Müller et al. ${ }^{39}$ found that $25-40 \%$ of participants with MDD reported 'almost always' daytime sleepiness, non-restorative sleep, attention deficits or memory complaints, with significant correlations between these variables $(p<0.05)$, as well as curvilinear associations between sleep duration and sleep quality (quadratic contrast, $p<0.05)$. However, Peng et al. ${ }^{40}$ reported no significant association between cognition and sleep disturbance $(r=0.029, p=0.219)$ in adolescents with first episode MDD.

Results in mixed MDD \& BD groups

Soehner and Harvey ${ }^{43}$ ( $N=639$ MDD participants; $N=138$ BD participants) reported that participants with a mood disorder and insomnia in the past year experienced 
significantly greater cognitive impairment in the past 30 days than participants with a mood disorder and no insomnia symptoms in the past year $(p=0.004)$.

\section{Methodological quality assessment}

Methodological quality assessment of studies using the EPHPP Quality Assessment Tool for Quantitative Studies ${ }^{31}$ are displayed in Supplementary Table 1. Selection bias was generally rated as moderate because in most studies participants were sampled from either outpatient clinics or inpatient settings. Study design was generally rated as weak because most were cross-sectional. Most studies controlled for at least $80 \%$ of relevant confounding variables, such as age, coffee consumption etc. Blinding was rated as moderate if it was not described, as was the case in almost all studies. Most studies used validated and reliable measures for sleep disturbance (e.g. Pittsburgh Sleep Quality Index, PSQI ${ }^{48}$ ) and cognition (e.g. MATRICS Consensus Cognitive Battery, $\mathrm{MCCB}^{49}$ ), and were therefore rated strong. Where applicable, withdrawals were reported satisfactorily by most studies. There was no association between global rating and positivity of findings.

\section{Discussion}

The purpose of this systematic review was to critically analyse the published literature on the relationship between sleep disturbance and cognitive impairment in BD and MDD. Fourteen studies were included in this review, for which quality assessment ranged from weak to strong.

Kanady et al. ${ }^{33}$ was the only RCT included in this review. This study, in which CBTI$\mathrm{BD}^{45}$ was administered to participants with $\mathrm{BD}$, found that a reduction in total wake time predicted improved working memory. The study also found that a reduction in sleep time variability predicted improved verbal learning. These findings suggest that sleep disturbance may contribute to cognitive impairment in BD, and that CBTI-BD may be an effective treatment. The remaining studies included in our review used either a longitudinal or cross-sectional design, and therefore did not allow for causal inferences to be made. 
medRxiv preprint doi: https://doi.org/10.1101/2021.08.12.21261470; this version posted August 13, 2021. The copyright holder for this preprint (which was not certified by peer review) is the author/funder, who has granted medRxiv a license to display the preprint in perpetuity.

All rights reserved. No reuse allowed without permission.

Ten of the twelve studies that measured sleep disturbance using subjective measures in participants with either MDD or BD found a significant association between sleep disturbance and cognitive impairment when adjusting for demographic and clinical covariates. In contrast, no significant association was reported in healthy participants, which suggests that this relationship may be specific to mood disorders. Given the strong evidence on the effect of objective sleep disturbance on cognitive impairment in healthy individuals ${ }^{24}$, this may indicate that subjective experience of sleep impairment may also increase risks for cognitive impairment in people with mood disorders. Some studies also found a curvilinear association, indicating that both extremely low ( $<5$ hours) and extremely high $(>11$ hours) self-reported sleep durations were associated with cognitive impairment; this was observed in participants with MDD (e.g. Mu $\square$ ller et al. ${ }^{39}$ ) and in BD (e.g. Laskemoen et al. $\left.{ }^{34}\right)$. However, there was also evidence to suggest that insomnia may have more deleterious effects on cognitive impairment than hypersomnia. For example, Laskemoen et al. $^{34}$ found a larger effect size between insomnia and processing speed $\left(F=15.43, p<0.001, \eta^{2}=0.019\right)$ than hypersomnia $(F=6.87, p<$ $\left.0.01, \eta^{2}=0.009\right)$ in people with BD.

The main disadvantage of using subjective measures to assess sleep disturbance in people with mood disorders is that there is a considerable risk of bias. Euthymic people with either BD or MDD tend to significantly underestimate sleep duration and quality. ${ }^{17,50}$ Indeed, Boland et al. ${ }^{32}$ found that people with BD had significantly higher insomnia severity index (ISI) scores than healthy participants (indicating worse sleep quality), yet found no significant difference between BD and healthy participants in objective sleep parameters, as measured by actigraphy. This effect may be due to maladaptive sleep-related beliefs developed during mood episodes, in which sleep disturbance is particularly severe, which are then carried over into euthymia. ${ }^{50}$ Nevertheless, subjective measures provide valuable information about the perception of sleep disturbance and sleep-related cognitions, and interventions of maladaptive sleep beliefs may be a useful way of treating sleep disturbance in mood disorders ${ }^{51}$. Although antidepressant treatment produces no change in maladaptive sleep beliefs in $\mathrm{MDD}^{50}$, Cognitive Behavioural Treatment for Insomnia (CBT-I) has been shown to significantly improve maladaptive sleep beliefs in people with insomnia. CBT-I has been found to significantly improve both subjective sleep 
measures, measured by sleep diaries, and objective sleep measures, measured by polysomnography (PSG). ${ }^{51}$ Therefore, sleep-related cognitions may be an important target for treating sleep disturbance and potentially cognitive impairment in people with mood disorders.

Only three studies included in this review measured sleep disturbance using objective measures: two examined sleep disturbance in participants with BD using actigraphy $^{27,32}$ and one investigated sleep disturbance in participants with MDD using polysomnography ${ }^{42}$. The MDD study that used polysomnography found that longer periods of wakefulness occurring after defined sleep onset were associated with psychomotor slowing, however these associations were not specific to MDD ${ }^{42}$. One advantage of polysomnography is that it is more accurate than actigraphy in recognising sleep and wake times, and is therefore the 'gold standard' of objective sleep measurement. Another key advantage of polysomnography is the ability to measure sleep architecture, however, the Wilckens et al MDD study did not report sleep architecture measurements.

Mood disorders are associated with several sleep architecture abnormalities, particularly altered distribution of rapid eye movement (REM) sleep in $M^{2} D^{52}$ and $\mathrm{BD}^{53}$. Components of sleep architecture have been linked to aspects of cognitive impairment in healthy individuals. For example, time in slow wave sleep contributes to processing speed in healthy individuals. ${ }^{54}$ Abnormal sleep architecture may be associated with cognitive impairment in mood disorders, so sleep architecture may be a highly relevant variable to measure. Moreover, knowledge of the specific components of sleep archiecture associated with improvements in mental health or cognition could be targeted in interventions for treatment or prevention. For example, enhancing slow oscillation activity via non-invasive auditory stimulation has been shown to improve memory in healthy individuals ${ }^{55}$. Thus, we suggest that future studies of the role of sleep in cognition in mood disorders use polysomnography where possible.

Interestingly, the two BD studies which used actigraphy had opposite findings. Bradley et al. ${ }^{27}$ found a significant association between objective sleep disturbance and cognitive impairment in participants with $\operatorname{BD}(p<0.001)$. Specifically, 
medRxiv preprint doi: https://doi.org/10.1101/2021.08.12.21261470; this version posted August 13, 2021. The copyright holder for this preprint (which was not certified by peer review) is the author/funder, who has granted medRxiv a license to display the preprint in perpetuity.

All rights reserved. No reuse allowed without permission.

participants with BD and abnormal sleep patterns were found to experience deficits in attention and executive function but normal verbal memory. In contrast, Boland et al. $^{32}$ found no significant association between objective sleep disturbance and cognitive impairment in participants with BD. However, this study included a relatively small sample size of participants with $B D(n=24)$ which implies low statistical power and risk of type-II error. Nevertheless, taken together, these two BD studies are inconclusive as to the association between objective sleep disturbance and cognitive impairment in people with BD and highlights the need for future research using larger sample sizes and PSG.

\section{Limitations}

This review reflects the limited number of studies in the field and so the relatively small number of participants in which the associations between sleep disturbance and cognitive impairment have been investigated, particularly regarding MDD, limits our power to draw wider conclusions. The studies included in our review generally had small sample sizes $(N=48$ - 4555), which limited statistical power and increased risks of type-II error. A meta-analysis was not performed because there was significant heterogeneity between studies in the age and mood state of participants, as well as the measures of sleep and cognition used.

In studies examining sleep disturbance and cognitive impairment in mood disorders, it is normally best practice to include only euthymic participants because mood state may affect both sleep disturbance and cognitive impairment, and therefore may be a confound. ${ }^{56}$ The MDD studies were particularly weak in this regard, as four of the five MDD studies only included people currently experiencing a depressive episode. The BD studies were stronger, but still varied: six studies only included participants that were euthymic, ${ }^{32,33,35,37,44,46}$ and two included participants in any mood state. ${ }^{27,34}$

With the exception of Wilckens et al. ${ }^{42}$, none of the included studies adjusted for the use of psychotropic medications in the relationship between sleep disturbance and cognitive impairment. Psychotropic medication may be a confounding variable, as they can affect both sleep and cognition in people with mood disorders. ${ }^{57}$ Indeed, Volkert et al. ${ }^{37}$ reported that antipsychotic treatment and polypharmacy were related to cognitive impairment. Furthermore, many antipsychotics affect REM sleep, which 
has been linked to emotional memory processing ${ }^{58}$. Without adjusting for the use of psychotropic medications, it is unclear which medications alter the relationship between sleep disturbance and cognitive impairment in mood disorders, and to what extent.

\section{Suggestions for future research}

Theoretically, sleep disturbance may cause, predispose or exacerbate cognitive impairment in mood disorders but this link has yet to be adequately evaluated. Further research is clearly needed in this area in participants with mood disorders. Based on the evaluation of current evidence, we would suggest that future studies follow five recommendations. First, studies should include only euthymic participants, to remove the confounding effect of mood state. Second, they should use objective measures of sleep, ideally polysomnography, to evaluate the role of sleep disturbance in mediating cognitive impairment, and to determine which aspects of sleep architecture are linked to cognition in these individuals. Third, all studies should use a comprehensive cognitive battery such as the BACS-A ${ }^{59}$ or ideally the ISBD-BANC $^{60}$. Fourth, analyses should adjust for the use of psychotropic medications, as these may also have a confounding effect. Finally, we would suggest that studies use a prospective longitudinal design, and, if possible, use a randomised clinical trial design for intervention studies.

\section{Conclusion}

In conclusion, our systematic review provides preliminary evidence for an association between sleep disturbance and cognitive impairment in mood disorders. The studies identified by this systematic review found increased rates of both subjective sleep disturbances and cognitive impairment in people with MDD and BD, compared to healthy participants. Ten of the twelve studies that measured sleep disturbance using subjective measures of sleep found a significant association between sleep disturbance and cognitive impairment across both diagnoses when adjusting for demographic and clinical covariates, whereas no significant association was found in healthy participants. In contrast, the evidence was scarcer and more conflicting with regards to whether objectively measured sleep abnormalities are associated with cognitive impairment in people with mood disorders: two out of three studies reported significant associations. Only one study ${ }^{33}$ conducted an 
medRxiv preprint doi: https://doi.org/10.1101/2021.08.12.21261470; this version posted August 13, 2021. The copyright holder for this preprint (which was not certified by peer review) is the author/funder, who has granted medRxiv a license to display the preprint in perpetuity.

All rights reserved. No reuse allowed without permission.

intervention, and reported that improved sleep predicted an improvement in cognition in BD. As cognitive impairment has significant implications for psychosocial functioning in people with mood disorders, these findings highlight the importance of effectively identifying and treating sleep disturbances in people with MDD and BD. 


\section{Contributors}

OP wrote the report with input from NUM, KWM, SAC, IR, AHY and PRAS. OP and NUM independently performed the literature search and quality assessment. All authors had full access to all the papers in the study and had final responsibility for the decision to submit for publication.

\section{Declaration of interests}

OP, NUM, SAC and IR declare no competing interests.

KWM has received consultancy fees from Lundbeck and Janssen-Cilag in the past three years.

PRAS reports non-financial support from Janssen Research and Development LLC, personal fees and non-financial support from Frontiers in Psychiatry, personal fees from Allergan, a grant from $\mathrm{H}$ Lundbeck, grants and non-financial support from Corcept Therapeutics, outside the submitted work.

AHY declares:

Employed by King's College London; Honorary Consultant SLaM (NHS UK)

Deputy Editor, BJPsych Open

Paid lectures and advisory boards for the following companies with drugs used in affective and related disorders:

Astrazenaca, Eli Lilly, Lundbeck, Sunovion, Servier, Livanova, Janssen, Allegan, Bionomics, Sumitomo Dainippon Pharma, COMPASS

Consultant to Johnson \& Johnson

Consultant to Livanova

Received honoraria for attending advisory boards and presenting talks at meetings organised by LivaNova. Principal Investigator in the Restore-Life VNS registry study funded by LivaNova.

Principal Investigator on ESKETINTRD3004: "An Open-label, Long-term, Safety and Efficacy Study of Intranasal Esketamine in Treatment-resistant Depression.”

Principal Investigator on "The Effects of Psilocybin on Cognitive Function in Healthy Participants"

Principal Investigator on "The Safety and Efficacy of Psilocybin in Participants with Treatment-Resistant Depression (P-TRD)"

UK Chief Investigator for Novartis MDD study MIJ821A12201

Grant funding (past and present): NIMH (USA); CIHR (Canada); NARSAD (USA); Stanley Medical Research Institute (USA); MRC (UK); Wellcome Trust (UK); Royal 
medRxiv preprint doi: https://doi.org/10.1101/2021.08.12.21261470; this version posted August 13, 2021. The copyright holder for this preprint (which was not certified by peer review) is the author/funder, who has granted medRxiv a license to display the preprint in perpetuity.

All rights reserved. No reuse allowed without permission.

College of Physicians (Edin); BMA (UK); UBC-VGH Foundation (Canada); WEDC (Canada); CCS Depression Research Fund (Canada); MSFHR (Canada); NIHR (UK). Janssen (UK)

No shareholdings in pharmaceutical companies 


\section{References}

1. McIntyre RS, Cha DS, Soczynska JK, et al. Cognitive deficits and functional outcomes in major depressive disorder: determinants, substrates, and treatment interventions. Depress Anxiety. 2013;30(6):515-527. doi:10.1002/da.22063

2. O’Donnell LA, Deldin PJ, Grogan-Kaylor A, et al. Depression and executive functioning deficits predict poor occupational functioning in a large longitudinal sample with bipolar disorder. J Affect Disord. 2017;215:135-142. doi:10.1016/j.jad.2017.03.015

3. Martino DJ, Igoa A, Scápola M, Marengo E, Samamé C, Strejilevich SA. Functional Outcome in the Middle Course of Bipolar Disorder: A Longitudinal Study. J Nerv Ment Dis. 2017;205(3):203—206. doi:10.1097/nmd.0000000000000583

4. Zhang B-H, Feng L, Feng Y, et al. The Effect of Cognitive Impairment on the Prognosis of Major Depressive Disorder. J Nerv Ment Dis. 2020;208(9).

https://journals.lww.com/jonmd/Fulltext/2020/09000/The_Effect_of_Cognitive_Impair ment_on_the.8.aspx

5. Depp CA, Mausbach BT, Harmell AL, et al. Meta $\square$ analysis of the association between cognitive abilities and everyday functioning in bipolar disorder. Bipolar Disord. 2012;14(3):217-226.

6. Cambridge OR, Knight MJ, Mills N, Baune BT. The clinical relationship between cognitive impairment and psychosocial functioning in major depressive disorder: A systematic review. Psychiatry Res. 2018;269:157-171. doi:10.1016/j.psychres.2018.08.033

7. Rock P, Roiser J, Riedel W, Blackwell A. Cognitive impairment in depression: a systematic review and meta-analysis. Psychol Med. 2014;44(10):2029.

8. Snyder HR. Major depressive disorder is associated with broad impairments on neuropsychological measures of executive function: A meta-analysis and review. Psychol Bull. 2013;139(1):81-132. doi:10.1037/a0028727

9. Kurtz MM, Gerraty RT. A meta-analytic investigation of neurocognitive deficits in bipolar illness: Profile and effects of clinical state. Neuropsychology. 2009;23(5):551562. doi:10.1037/a0016277

10. Semkovska M, Quinlivan L, O'Grady T, et al. Cognitive function following a major depressive episode: a systematic review and meta-analysis. Lancet Psychiatry. 2019;6(10):851-861. doi:10.1016/S2215-0366(19)30291-3

11. Bora E, Yucel M, Pantelis C. Cognitive endophenotypes of bipolar disorder: A metaanalysis of neuropsychological deficits in euthymic patients and their first-degree relatives. J Affect Disord. 2009;113(1-2):1-20. doi:10.1016/j.jad.2008.06.009

12. Pu S, Noda T, Setoyama S, Nakagome K. Empirical evidence for discrete neurocognitive subgroups in patients with non-psychotic major depressive disorder: clinical implications. Psychol Med. 2018;48(16):2717-2729. doi:10.1017/S003329171800034X 
medRxiv preprint doi: https://doi.org/10.1101/2021.08.12.21261470; this version posted August 13, 2021. The copyright holder for this preprint (which was not certified by peer review) is the author/funder, who has granted medRxiv a license to display the preprint in perpetuity. All rights reserved. No reuse allowed without permission.

13. Burdick KE, Russo M, Frangou S, et al. Empirical evidence for discrete neurocognitive subgroups in bipolar disorder: clinical implications. Psychol Med. 2014;44(14):30833096. doi:10.1017/S0033291714000439

14. Jensen JH, Knorr U, Vinberg M, Kessing LV, Miskowiak KW. Discrete neurocognitive subgroups in fully or partially remitted bipolar disorder: Associations with functional abilities. J Affect Disord. 2016;205:378-386.

15. Depp CA, Dev S, Eyler LT. Bipolar Depression and Cognitive Impairment. Psychiatr Clin North Am. 2016;39(1):95-109. doi:10.1016/j.psc.2015.09.004

16. American Psychiatric Association, American Psychiatric Association, eds. Diagnostic and Statistical Manual of Mental Disorders: DSM-5. 5th ed. American Psychiatric Association; 2013.

17. Harvey AG, Schmidt DA, Scarnà A, Semler CN, Goodwin GM. Sleep-Related Functioning in Euthymic Patients With Bipolar Disorder, Patients With Insomnia, and Subjects Without Sleep Problems. Am J Psychiatry. 2005;162(1):50-57. doi:10.1176/appi.ajp.162.1.50

18. Iovieno N, van Nieuwenhuizen A, Clain A, Baer L, Nierenberg AA. Residual symptoms after remission of major depressive disorder with fluoxetine and risk of relapse. Depress Anxiety. 2011;28(2):137-144.

19. Nierenberg AA, Keefe BR, Leslie VC, et al. Residual symptoms in depressed patients who respond acutely to fluoxetine. J Clin Psychiatry. 1999;60(4):221-225.

20. Carney CE, Segal ZV, Edinger JD, Krystal AD. A comparison of rates of residual insomnia symptoms following pharmacotherapy or cognitive-behavioral therapy for major depressive disorder. J Clin Psychiatry. Published online 2007.

21. Sylvia LG, Dupuy JM, Ostacher MJ, et al. Sleep disturbance in euthymic bipolar patients. J Psychopharmacol (Oxf). 2012;26(8):1108-1112.

doi:10.1177/0269881111421973

22. Li SX, Lam SP, Chan JWY, Yu MWM, Wing Y-K. Residual Sleep Disturbances in Patients Remitted From Major Depressive Disorder: A 4-Year Naturalistic Follow-up Study. Sleep. 2012;35(8):1153-1161. doi:10.5665/sleep.2008

23. Jackson A, Cavanagh J, Scott J. A systematic review of manic and depressive prodromes. J Affect Disord. 2003;74(3):209-217.

24. Krause AJ, Simon EB, Mander BA, et al. The sleep-deprived human brain. Nat Rev Neurosci. 2017;18(7):404-418. doi:10.1038/nrn.2017.55

25. Ashton JE, Harrington MO, Langthorne D, Ngo H-VV, Cairney SA. Sleep deprivation induces fragmented memory loss. Learn Mem. 2020;27(4):130-135.

26. Harrington MO, Ashton JE, Sankarasubramanian S, Anderson MC, Cairney SA. Losing Control: Sleep Deprivation Impairs the Suppression of Unwanted Thoughts. Published online 2021:17. 
medRxiv preprint doi: https://doi.org/10.1101/2021.08.12.21261470; this version posted August 13, 2021. The copyright holder for this preprint (which was not certified by peer review) is the author/funder, who has granted medRxiv a license to display the preprint in perpetuity. All rights reserved. No reuse allowed without permission.

27. Bradley AJ, Anderson KN, Gallagher P, McAllister-Williams RH. The association between sleep and cognitive abnormalities in bipolar disorder. Psychol Med. 2020;50(1):125-132. doi:10.1017/S0033291718004038

28. Page MJ, McKenzie JE, Bossuyt PM, et al. The PRISMA 2020 statement: an updated guideline for reporting systematic reviews. BMJ. Published online March 29, 2021:n71. doi:10.1136/bmj.n71

29. World Health Organization. International Classification of Diseases—Ninth Revision (ICD-9). Wkly Epidemiol Rec. 1988;63(45):343-344.

30. American Psychiatric Association. Diagnostic and Statistical Manual of Mental Disorders (3rd Ed.).; 1980.

31. Thomas H, Ciliska D, Dobbins M. Quality assessment tool for quantitative studies. Tor Eff Public Health Pract Proj McMaster Univ. Published online 2003.

32. Boland EM, Stange JP, Molz Adams A, et al. Associations between sleep disturbance, cognitive functioning and work disability in Bipolar Disorder. Psychiatry Res. 2015;230(2):567-574. doi:10.1016/j.psychres.2015.09.051

33. Kanady JC, Soehner AM, Klein AB, Harvey AG. The association between insomniarelated sleep disruptions and cognitive dysfunction during the inter-episode phase of bipolar disorder. J Psychiatr Res. 2017;88:80-88. doi:10.1016/j.jpsychires.2017.01.001

34. Laskemoen JF, Büchmann C, Barrett EA, et al. Do sleep disturbances contribute to cognitive impairments in schizophrenia spectrum and bipolar disorders? Eur Arch Psychiatry Clin Neurosci. Published online October 5, 2019. doi:10.1007/s00406-01901075-0

35. Samalin L, Boyer L, Murru A, et al. Residual depressive symptoms, sleep disturbance and perceived cognitive impairment as determinants of functioning in patients with bipolar disorder. J Affect Disord. 2017;210:280-286. doi:10.1016/j.jad.2016.12.054

36. Ullah MH. Effects of sleep disturbance on cognitive functioning in bipolar disorder type 1: a correlational study design. ProQuest Diss Publ. Published online 2017.

37. Volkert J, Kopf J, Kazmaier J, et al. Evidence for cognitive subgroups in bipolar disorder and the influence of subclinical depression and sleep disturbances. Eur Neuropsychopharmacol. 2015;25(2):192-202. doi:10.1016/j.euroneuro.2014.07.017

38. Cabanel N, Schmidt A-M, Fockenberg S, et al. Evening preference and poor sleep independently affect attentional-executive functions in patients with depression. Psychiatry Res. 2019;281:112533. doi:10.1016/j.psychres.2019.112533

39. Müller MJ, Olschinski C, Kundermann B, Cabanel N. Sleep duration of inpatients with a depressive disorder: associations with age, subjective sleep quality, and cognitive complaints. Arch Psychiatr Nurs. 2017;31(1):77-82. doi:10.1016/j.apnu.2016.08.008

40. Peng S, Li J, Wu Z, et al. Characteristics of and factors influencing cognitive impairment in adolescent patients with first-episode depression. Vulnerable Child Youth Stud. 2018;13(4):317-324. doi:10.1080/17450128.2018.1515517 
41. Cha DS, Carmona N, Cha RH, et al. Perceived sleep quality predicts cognitive function in adults with major depressive disorder independent of depression severity. Ann Clin PSYCHIATRY. Published online 2019:10.

42. Wilckens KA, Kline CE, Bowman MA, et al. Does objectively-assessed sleep moderate the association between history of major depressive disorder and task-switching? $J$ Affect Disord. 2020;265:216-223. doi:10.1016/j.jad.2020.01.003

43. Soehner AM, Harvey AG. Prevalence and Functional Consequences of Severe Insomnia Symptoms in Mood and Anxiety Disorders: Results from a Nationally Representative Sample. Sleep. 2012;35(10):1367-1375. doi:10.5665/sleep.2116

44. Russo M, Mahon K, Shanahan M, et al. The relationship between sleep quality and neurocognition in bipolar disorder. J Affect Disord. 2015;187:156-162. doi:10.1016/j.jad.2015.08.009

45. Harvey AG, Soehner AM, Kaplan KA, et al. Treating insomnia improves mood state, sleep, and functioning in bipolar disorder: A pilot randomized controlled trial. J Consult Clin Psychol. 2015;83(3):564-577. doi:10.1037/a0038655

46. Samalin L, de Chazeron I, Vieta E, Bellivier F, Llorca P-M. Residual symptoms and specific functional impairments in euthymic patients with bipolar disorder. Bipolar Disord. 2016;18(2):164-173. doi:10.1111/bdi.12376

47. White DA, Myerson J, Hale S. How cognitive is psychomotor slowing in depression? evidence from a meta-analysis. Aging Neuropsychol Cogn. 1997;4(3):166-174. doi:10.1080/13825589708256645

48. Buysse DJ, Reynolds III CF, Monk TH, Berman SR, Kupfer DJ. The Pittsburgh Sleep Quality Index: a new instrument for psychiatric practice and research. Psychiatry Res. 1989;28(2):193-213.

49. Wysokinski A, Dzienniak M, Kloszewska I. Assessment of cognitive performance using CNS vital signs after electroconvulsive treatment of schizophrenia. $J$ ECT. 2014;30(1):e5-e6.

50. Carney CE, Harris AL, Friedman J, Segal ZV. Residual sleep beliefs and sleep disturbance following cognitive behavioral therapy for major depression. Depress Anxiety. 2011;28(6):464-470.

51. Morin C, Blais F, Savard J. Are changes in beliefs and attitudes about sleep related to sleep improvements in the treatment of insomnia? Behav Res Ther. 2002;40(7):741-752.

52. Hutka P, Krivosova M, Muchova Z, et al. Association of Sleep Architecture and Physiology with Depressive Disorder and Antidepressants Treatment. Int J Mol Sci. 2021;22(3):1333. doi:10.3390/ijms22031333

53. Eidelman P, Talbot LS, Gruber J, Hairston I, Harvey AG. Sleep architecture as correlate and predictor of symptoms and impairment in inter-episode bipolar disorder: taking on the challenge of medication effects: Sleep and inter-episode bipolar disorder. J Sleep Res. 2010;19(4):516-524. doi:10.1111/j.1365-2869.2010.00826.x 
medRxiv preprint doi: https://doi.org/10.1101/2021.08.12.21261470; this version posted August 13, 2021. The copyright holder for this preprint (which was not certified by peer review) is the author/funder, who has granted medRxiv a license to display the preprint in perpetuity.

All rights reserved. No reuse allowed without permission.

54. della Monica C, Johnsen S, Atzori G, Groeger JA, Dijk D-J. Rapid Eye Movement Sleep, Sleep Continuity and Slow Wave Sleep as Predictors of Cognition, Mood, and Subjective Sleep Quality in Healthy Men and Women, Aged 20-84 Years. Front Psychiatry. 2018;9:255. doi:10.3389/fpsyt.2018.00255

55. Ngo H-VV, Martinetz T, Born J, Mölle M. Auditory closed-loop stimulation of the sleep slow oscillation enhances memory. Neuron. 2013;78(3):545-553.

56. Miskowiak K, Burdick K, Martinez-Aran A, et al. Assessing and addressing cognitive impairment in bipolar disorder: the International Society for Bipolar Disorders Targeting Cognition Task Force recommendations for clinicians. Bipolar Disord. 2018;20(3):184-194. doi:10.1111/bdi.12595

57. Staner L. Sleep disturbances, psychiatric disorders, and psychotropic drugs. Dialogues Clin Neurosci. 2005;7(4):323.

58. Walker MP, van Der Helm E. Overnight therapy? The role of sleep in emotional brain processing. Psychol Bull. 2009;135(5):731.

59. Keefe RS, Goldberg TE, Harvey PD, Gold JM, Poe MP, Coughenour L. The Brief Assessment of Cognition in Schizophrenia: reliability, sensitivity, and comparison with a standard neurocognitive battery. Schizophr Res. 2004;68(2-3):283-297.

60. Yatham LN, Torres IJ, Malhi GS, et al. The international society for bipolar disordersbattery for assessment of neurocognition (ISBD $\square$ BANC). Bipolar Disord. 2010;12(4):351-363.

61. Fietze I, Wiesenacker D, Blau A, Penzel T. Sleep quality in a hospital and effects of noise. Somnologie-Schlafforschung Schlafmed. 2008;12(2):167.

62. Wechsler D. Wechsler Test of Adult Reading: WTAR: Psychological Corporation. San Antonio Tx. Published online 2001.

63. Wechsler D. Wechsler Memory Scale (WMS-III). Vol 14. Psychological corporation San Antonio, TX; 1997.

64. Morin CM. Insomnia: Psychological Assessment and Management. Guilford press; 1993.

65. Rush AJ, Gullion CM, Basco MR, Jarrett RB, Trivedi MH. The inventory of depressive symptomatology (IDS): psychometric properties. Psychol Med. 1996;26(3):477-486.

66. Endicott J, Spitzer R. Schedule for affective disorders and schizophrenia (SADS). Acta Psychiatr Belg. 1987;87(4):361-516.

67. Montgomery SA, Åsberg M. A new depression scale designed to be sensitive to change. Br J Psychiatry. 1979;134(4):382-389.

68. Kaufman AS. Manual for the Kaufman brief intelligence test. Circ Pines MN Am Guid Serv. Published online 1990. 
medRxiv preprint doi: https://doi.org/10.1101/2021.08.12.21261470; this version posted August 13, 2021. The copyright holder for this preprint (which was not certified by peer review) is the author/funder, who has granted medRxiv a license to display the preprint in perpetuity.

All rights reserved. No reuse allowed without permission.

69. Delis DC, Kramer JH, Kaplan E, Holdnack J. Reliability and validity of the DelisKaplan Executive Function System: an update. J Int Neuropsychol Soc JINS. 2004;10(2):301.

70. Shallice T. Specific impairments of planning. Philos Trans R Soc Lond B Biol Sci. 1982;298(1089):199-209.

71. Niemann H, Sturm W, Thöne-Otto A, Wilmes K. California verbal learning test, version 21. Mödling Schuhfried GmbH. Published online 2011.

72. Woods SP, Delis DC, Scott JC, Kramer JH, Holdnack JA. The California Verbal Learning Test-second edition: test-retest reliability, practice effects, and reliable change indices for the standard and alternate forms. Arch Clin Neuropsychol. 2006;21(5):413420.

73. Nelson HE. National Adult Reading Test (NART): For the Assessment of Premorbid Intelligence in Patients with Dementia: Test Manual. Nfer-Nelson; 1982.

74. Dinges DF, Powell JW. Microcomputer analyses of performance on a portable, simple visual RT task during sustained operations. Behav Res Methods Instrum Comput. 1985;17(6):652-655.

75. Fan J, McCandliss BD, Sommer T, Raz A, Posner MI. Testing the efficiency and independence of attentional networks. J Cogn Neurosci. 2002;14(3):340-347.

76. Pariante CM, Alhaj HA, Arulnathan VE, et al. Central glucocorticoid receptor-mediated effects of the antidepressant, citalopram, in humans: a study using EEG and cognitive testing. Psychoneuroendocrinology. 2012;37(5):618-628.

77. Samalin L, Llorca PM, Giordana B, et al. Residual symptoms and functional performance in a large sample of euthymic bipolar patients in France (the OPTHYMUM study). J Affect Disord. 2014;159:94-102.

78. Rosa AR, Sánchez-Moreno J, Martínez-Aran A, et al. Validity and reliability of the Functioning Assessment Short Test (FAST) in bipolar disorder. Clin Pract Epidemiol Ment Health. 2007;3(1):5.

79. Glahn DC, Almasy L, Barguil M, et al. Neurocognitive endophenotypes for bipolar disorder identified in multiplex multigenerational families. Arch Gen Psychiatry. 2010;67(2):168-177.

80. Zimmermann P, Fimm B. A test battery for attentional performance. Appl Neuropsychol Atten Theory Diagn Rehabil. 2002;110:151.

81. Aschenbrenner S, Tucha O, Lange K. Manual zum RWT (Regensburger Wortflüssigkeits-Test; Handanweisung). Published online 2000.

82. Johns MW. A new method for measuring daytime sleepiness: the Epworth sleepiness scale. sleep. 1991;14(6):540-545. 
Tables

Table 1. Characteristics and findings of studies examining sleep disturbance and cognitive impairment in MDD

\begin{tabular}{|c|c|c|c|c|c|}
\hline Study & $\begin{array}{c}\text { Mood } \\
\text { disorder(s) } \\
\text { studied }\end{array}$ & Participants & Measures & Main findings & Limitations \\
\hline $\begin{array}{l}\text { Cabanel et } \\
\text { al. }\end{array}$ & MDD & \begin{tabular}{|l|} 
Total $\mathrm{N}=63$ \\
$\mathrm{~N}=34 \mathrm{MDD}$ \\
participants \\
(27 with single \\
and 7 with \\
recurrent \\
depression; 9 \\
with comorbid \\
anxiety \\
disorders), \\
mean age 33.0 \\
\pm 8.9 \\
$\mathrm{~N}=29$ healthy \\
participants, \\
mean age 31.5 \\
\pm 7.8
\end{tabular} & $\begin{array}{l}\text { Aleep: PSQI } \\
\text { Cognition: TMT- } \\
\text { AMT-B } \\
\text { SMT- }\end{array}$ & $\begin{array}{l}\text { Patients with severely impaired sleep quality (PSQI > } \\
\text { 10) had significantly poorer performance on the } \\
\text { TMT-A (visuomotor processing speed; } p=0.011 \text { ) } \\
\text { and the TMT-B (executive function; } p=0.015) \\
\text { and remained significant after Bonferroni correction } \\
\text { ( } \alpha=0.025 \text { per tests), than patients with no or } \\
\text { moderately impaired sleep quality (PSQI > 10). }\end{array}$ & $\begin{array}{l}\text { The use of } \\
\text { subjective measure } \\
\text { of sleep instead of } \\
\text { objective sleep } \\
\text { battery. Neuropsych } \\
\text { ological } \\
\text { assessment only } \\
\text { evaluated a } \\
\text { subdomain of } \\
\text { executive functions. } \\
\text { Particularly small } \\
\text { sample size. }\end{array}$ \\
\hline
\end{tabular}




\begin{tabular}{|c|c|c|c|c|c|}
\hline Cha et al. & MDD & $\begin{array}{l}\text { Total } \mathrm{N}=200, \\
\text { aged } 18 \text { to } 65 \\
\mathrm{~N}=100 \\
\text { participants } \\
\text { with recurrent } \\
\text { MDD } \\
\mathrm{N}=100 \text { sex-, } \\
\text { age- } \\
\text { education- } \\
\text { matched } \\
\text { healthy } \\
\text { participants }\end{array}$ & $\begin{array}{l}\text { Sleep: PSQI } \\
\text { Cognition: } \\
\text { computerised } \\
\text { cognitive } \\
\text { assessment } \\
\text { tool THINC- } \\
\text { integrated } \\
\text { tool that } \\
\text { included } \\
\text { CRT, the One } \\
\text { Back Memory } \\
\text { task, DSST, } \\
\text { TMT-B, PDQ-5- } \\
\text { D. }\end{array}$ & $\begin{array}{l}\text { Sleep quality predicted impairments in subjective } \\
\text { cognitive performance }(p<0.001) \text { and objective } \\
\text { cognitive impairments }(p=0.017) \text {. Depression } \\
\text { severity was a partial mediator of the relationship } \\
\text { between subjective cognitive function and sleep } \\
\text { quality ( } B=-0.43 ; 95 \% \mathrm{Cl},-0.56,-0.33) \text {. After } \\
\text { controlling for the depression severity, the direct } \\
\text { effect of sleep quality on subjective cognition } \\
\text { performance remained significant }(B=-0.18 ; 95 \% \mathrm{Cl}, \\
-0.30,-0.07) \text {. }\end{array}$ & $\begin{array}{l}\text { The use of } \\
\text { subjective measure } \\
\text { of sleep instead of } \\
\text { objective sleep } \\
\text { battery. Complete } \\
\text { case analysis of } \\
\text { cognitive tests } \\
\text { resulting in low } \\
\text { statistical power. }\end{array}$ \\
\hline $\begin{array}{l}\text { Wilckens et } \\
\text { al. }\end{array}$ & MDD & $\begin{array}{l}\text { Total } \mathrm{N}=53, \\
\text { aged } 48 \text { to } 79 \\
\text { years of age } \\
\mathrm{N}=17 \\
\text { participants } \\
\text { with recurrent }\end{array}$ & $\begin{array}{l}\text { Sleep: two } \\
\text { nights of PSG } \\
\text { Cognition: } \\
\text { computer-based } \\
\text { task-switching } \\
\text { paradigm }\end{array}$ & $\begin{array}{l}\text { Higher wake after sleep onset and shorter total sleep } \\
\text { time were linearly associated with slower response } \\
\text { time across single-task }(p=0.10) \text { and switching } \\
\text { blocks }(p=0.005) \text {; however, these associations were } \\
\text { not specific to MDD. }\end{array}$ & $\begin{array}{l}\text { Participants with } \\
\text { history of MDD } \\
\text { were more likely to } \\
\text { take } \\
\text { antidepressants at } \\
\text { the time of the }\end{array}$ \\
\hline
\end{tabular}




\begin{tabular}{|c|c|c|c|c|c|}
\hline & & $\begin{array}{l}\text { MDD } \\
\text { N=36 } \\
\text { participants } \\
\text { with no } \\
\text { recurrent } \\
\text { MDD } \\
\mathrm{N}=28 \\
\text { participants } \\
\text { with no lifetime } \\
\text { MDD } \\
\text { N=25 } \\
\text { participants } \\
\text { with lifetime } \\
\text { MDD }\end{array}$ & & & $\begin{array}{l}\text { study, thus possibly } \\
\text { affecting sleep } \\
\text { and/or } \\
\text { cognition. Did not } \\
\text { exclude ages } \\
\text { 65. Particularly } \\
\text { small sample size. }\end{array}$ \\
\hline $\begin{array}{c}\text { Mu } \square \text { ller et } \\
\text { al. }^{29}\end{array}$ & MDD & $\begin{array}{l}\text { Total } \mathrm{N}=154, \\
\text { aged 19-89 } \\
\mathrm{N}=154 \mathrm{MDD} \\
\text { participants }\end{array}$ & $\begin{array}{l}\text { Sleep: SQH } \\
\text { Cognition: SQH } \\
\text { (items } \\
\text { pertaining to } \\
\text { daytime } \\
\text { attention deficits } \\
\text { and memory }\end{array}$ & $\begin{array}{l}25-40 \% \text { of participants with MDD reported 'almost } \\
\text { always' daytime sleepiness, non-restorative sleep, } \\
\text { attention deficits or memory complaints, with } \\
\text { significant correlations } \\
\text { between these variables }(p<0.05) \text {, as well } \\
\text { as curvilinear associations between sleep duration } \\
\text { and sleep quality (quadratic contrast, } p<0.05 \text { ). }\end{array}$ & $\begin{array}{l}\text { The use of } \\
\text { subjective measure } \\
\text { of sleep instead of } \\
\text { objective sleep } \\
\text { battery. Did not use } \\
\text { a validated } \\
\text { measure of }\end{array}$ \\
\hline
\end{tabular}




\begin{tabular}{|c|c|c|c|c|c|}
\hline & & & $\begin{array}{l}\text { complaints } \\
\text { only) }\end{array}$ & & $\begin{array}{l}\text { cognition. No } \\
\text { control group. }\end{array}$ \\
\hline $\begin{array}{l}\text { Peng et } \\
\text { al. }^{31}\end{array}$ & MDD & $\begin{array}{l}\text { Total } \mathrm{N}=178, \\
\text { aged } 15-30 \\
\mathrm{~N}=128 \text { first- } \\
\text { episode MDD } \\
\text { participants } \\
\mathrm{N}=50 \text { healthy } \\
\text { participants }\end{array}$ & $\begin{array}{l}\text { Sleep: PSQI } \\
\text { Cognition: } \\
\text { MCCB }\end{array}$ & $\begin{array}{l}\text { No significant association between cognition anc } \\
\text { sleep disturbance } \quad(r=0.029, p=0.219) \text { ir } \\
\text { adolescents with first episode MDD. }\end{array}$ & $\begin{array}{l}\text { The use of } \\
\text { subjective measure } \\
\text { of sleep instead of } \\
\text { objective sleep } \\
\text { battery. Included } \\
\text { participants aged } \\
\text { <18. }\end{array}$ \\
\hline $\begin{array}{l}\text { Boland et } \\
\qquad \text { al. }^{32}\end{array}$ & BD & $\begin{array}{l}\text { Total } \mathrm{N}=48 \\
\text { aged } 18-65 \\
\mathrm{~N}=24 \\
\text { euthymic BD } \\
\text { participants } \\
\mathrm{N}=24 \text { healthy } \\
\text { participants }\end{array}$ & $\begin{array}{l}\text { Sleep: ISI, UCII, } \\
\text { PSQI, wrist } \\
\text { actigraphy } \\
\text { Cognition: KBIT- } \\
\text { II, DKEFS } \\
\text { (Stroop subtest } \\
\text { only), Tower of } \\
\text { London, CVLT- } \\
\text { II, WMS-III (digit } \\
\text { span subtest } \\
\text { only) }\end{array}$ & $\begin{array}{l}\text { No significant associations between sleep } \\
\text { disturbance (including objective } \\
\text { measures) and cognition, except for a significant } \\
\text { negative correlation between daytime dysfunction } \\
\text { due to sleep disturbance and working memory }(r= \\
-0.57, p=0.03) \text {. }\end{array}$ & $\begin{array}{l}\text { Particularly small } \\
\text { sample size. }\end{array}$ \\
\hline
\end{tabular}




\begin{tabular}{|c|c|c|c|c|c|}
\hline $\begin{array}{c}\text { Bradley et } \\
\text { al. }^{24}\end{array}$ & BD & $\begin{array}{l}\text { Total } \mathrm{N}=88 \\
\text { aged } 18-65 \\
\mathrm{~N}=46 \mathrm{BD} \\
\text { participants, in } \\
\text { any mood } \\
\text { state } \\
\mathrm{N}=42 \text { healthy } \\
\text { control } \\
\text { participants }\end{array}$ & $\begin{array}{l}\text { Sleep: wrist } \\
\text { actigraphy } \\
\text { Cognitive } \\
\text { assessment: } \\
\text { NART, PVT, } \\
\text { ANT, DSST, } \\
\text { NSMT }\end{array}$ & $\begin{array}{l}\text { People with BD with normal sleep patterns were not } \\
\text { significantly different to healthy participants in } \\
\text { cognitive functions, but people with BD and } \\
\text { sleep disturbance (including objective } \\
\text { measures) performed significantly worse in cognitive } \\
\text { tests than healthy participants }(p<0.001) \text {. }\end{array}$ & $\begin{array}{l}\text { Did not adjust for } \\
\text { the mood state of } \\
\text { participants. } \\
\text { Particularly small } \\
\text { sample size. }\end{array}$ \\
\hline 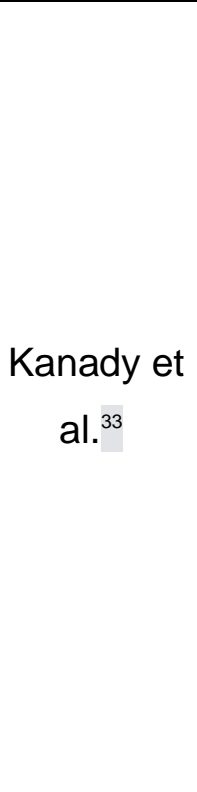 & BD & $\begin{array}{l}\text { Total } \mathrm{N}=66, \\
\text { aged 18-65 } \\
47 \text { euthymic } \\
\mathrm{BD} \\
\text { participants } \\
\text { with comorbid } \\
\text { insomnia } \\
19 \text { BD } \\
\text { participants } \\
\text { without sleep } \\
\text { disturbance in } \\
\text { the last six }\end{array}$ & $\begin{array}{l}\text { Sleep: ISI, } \\
\text { PSQI, DSISD, } \\
\text { sleep diary } \\
\text { Cognition: N- } \\
\text { Back Task and } \\
\text { WMS-III (digit } \\
\text { span subtest } \\
\text { only) }\end{array}$ & $\begin{array}{l}\text { Greater sleep time variability predicted poorer } \\
\text { working memory }(p<0.01) \text { and verbal learning } \\
\text { performance }(p<0.01) \text { in BD. Furthermore, following } \\
\text { treatment of cognitive behaviour therapy for insomnia } \\
\text { modified for bipolar disorder }\left(C B T I-B^{38}\right) \text {, a reduction } \\
\text { in total wake time predicted improved working } \\
\text { memory }(p<0.05) \text { and a reduction in sleep time } \\
\text { variability predicted improved verbal } \\
\text { learning }(p<0.05) \text {. }\end{array}$ & $\begin{array}{l}\text { No healthy } \\
\text { control group. } \\
\text { Particularly small } \\
\text { sample size. }\end{array}$ \\
\hline
\end{tabular}




\begin{tabular}{|c|c|c|c|c|c|}
\hline & & months & & & \\
\hline $\begin{array}{c}\text { Laskemoen } \\
\text { et al. }{ }^{34}\end{array}$ & BD & $\begin{array}{l}\text { Total } \mathrm{N}=979, \\
\text { aged } 18-65 \\
\mathrm{~N}=340 \mathrm{BD} \\
\text { participants, in } \\
\text { any mood } \\
\text { state } \\
\mathrm{N}=457 \\
\text { schizophrenia } \\
\text { participants } \\
\mathrm{N}=182 \\
\text { healthy control } \\
\text { participants }\end{array}$ & $\begin{array}{l}\text { Sleep: IDS-C } \\
\text { (items } \\
\text { pertaining to } \\
\text { sleep } \\
\text { disturbance) } \\
\text { Cognition: } \\
\text { MCCB }\end{array}$ & $\begin{array}{l}\text { Significant associations } \\
\text { between insomnia and processing } \\
\text { speed }(p<0.001) \text {, insomnia and inhibition }(p<0.01) \text {, } \\
\text { hypersomnia and processing speed }(p<0.01) \text {, } \\
\text { and hypersomnia and inhibition }(p<0.05) \text { in people } \\
\text { with BD, whereas no association between sleep } \\
\text { disturbances and cognition was found in healthy } \\
\text { participants. }\end{array}$ & $\begin{array}{l}\text { The use of } \\
\text { subjective measure } \\
\text { of sleep instead of } \\
\text { objective sleep } \\
\text { battery. Did not } \\
\text { ydjust for the mood } \\
\text { participants. }\end{array}$ \\
\hline $\begin{array}{c}\text { Russo et } \\
\text { al. }\end{array}$ & BD & $\begin{array}{l}\text { Total } \mathrm{N}=117 \\
\text { aged } 18-65 \\
\mathrm{~N}=117 \\
\text { euthymic BD } \\
\text { participants }\end{array}$ & $\begin{array}{l}\text { Sleep: ESS, } \\
\text { PSQI } \\
\text { Cognition: } \\
\text { MCCB }\end{array}$ & $\begin{array}{l}\text { Sleep disturbance was significantly negatively } \\
\text { associated with social cognition }(r=-0.273, p \\
=0.004) \text {, and approached significance with working } \\
\text { memory }(r=-0.179, p=0.061) \text { and visual learning ( } r \\
=-0.161, p=0.094) \text {. } \\
\text { Path analyses indicated that social cognition and } \\
\text { working memory were directly (negatively) predicted } \\
\text { by sleep disruptions. }\end{array}$ & $\begin{array}{l}\text { No control group. } \\
\text { Only used } \\
\text { subjective } \\
\text { measures of sleep. }\end{array}$ \\
\hline
\end{tabular}




\begin{tabular}{|c|c|c|c|c|c|}
\hline $\begin{array}{l}\text { Samalin et } \\
\text { al. }^{35}\end{array}$ & BD & $\begin{array}{l}\text { Total } \mathrm{N}=468, \\
\text { aged }>18 \\
\mathrm{~N}=468 \\
\text { euthymic BD } \\
\text { participants }\end{array}$ & $\begin{array}{l}\text { Sleep: PSQI } \\
\text { Cognition: VAS } \\
\text { and FAST }\end{array}$ & $\begin{array}{l}\text { Sleep disturbances were indirectly associated } \\
\text { with functioning (including cognition) via residual } \\
\text { depressive symptoms and perceived cognitive } \\
\text { performance }(p=0.001) \text {. }\end{array}$ & $\begin{array}{l}\text { The use of } \\
\text { subjective } \\
\text { measures of } \\
\text { cognitive } \\
\text { functioning and } \\
\text { sleep instead of } \\
\text { objective } \\
\text { neuropsychological } \\
\text { and sleep } \\
\text { batteries. Did not } \\
\text { exclude ages > } 65 . \\
\text { No control group. }\end{array}$ \\
\hline $\begin{array}{c}\text { Samalin et } \\
\text { al. }\end{array}$ & BD & $\begin{array}{l}\text { Total } \mathrm{N}= \\
468, \text { mean age } \\
47.7 \pm 12.5 \\
\mathrm{~N}=468 \text { adult } \\
\text { outpatients } \\
\text { with bipolar I } \\
\text { disorder or } \\
\text { bipolar II } \\
\text { disorder }\end{array}$ & $\begin{array}{l}\text { Sleep: PSQI } \\
\text { Cognition: VAS } \\
\text { and FAST }\end{array}$ & $\begin{array}{l}\text { Participants with impaired cognitive functioning had } \\
\text { significantly higher scores ( } \mathrm{p}<0.02) \text {, and thus more } \\
\text { severe sleep disruptions, on PSQI than participants } \\
\text { with satisfactory cognitive functioning. }\end{array}$ & $\begin{array}{l}\text { The use of } \\
\text { subjective } \\
\text { measures of } \\
\text { cognitive } \\
\text { functioning and } \\
\text { sleep instead of } \\
\text { objective } \\
\text { neuropsychological } \\
\text { and sleep }\end{array}$ \\
\hline
\end{tabular}




\begin{tabular}{|c|c|c|c|c|c|}
\hline & & $\begin{array}{l}\text { in an euthymic } \\
\text { period }\end{array}$ & & & $\begin{array}{l}\text { batteries. } \\
\text { Did not exclude } \\
\text { ages }>65 \text {. No } \\
\text { control group. }\end{array}$ \\
\hline $\begin{array}{l}\text { Volkert et } \\
\qquad \text { al. }^{37}\end{array}$ & BD & $\begin{array}{l}\text { Total } \mathrm{N}=140 \\
\text { aged } 18-65 \\
\mathrm{~N}=70 \\
\text { euthymic } \mathrm{BD} \\
\text { participants } \\
\mathrm{N}=70 \text { healthy } \\
\text { participants }\end{array}$ & $\begin{array}{l}\text { Sleep: MADRS } \\
\text { (item pertaining } \\
\text { to sleep } \\
\text { disturbance) } \\
\text { Cognition: TAP, } \\
\text { CVLT, TOL, } \\
\text { RWT }\end{array}$ & $\begin{array}{l}\text { People with BD suffering from persistent sleep } \\
\text { disturbances show more severe cognitive } \\
\text { dysfunctions }(p<0.05)\end{array}$ & $\begin{array}{l}\text { Did not use a } \\
\text { validated measure } \\
\text { of sleep } \\
\text { disturbance. }\end{array}$ \\
\hline $\begin{array}{l}\text { Soehner } \\
\text { and } \\
\text { Harvey }^{43}\end{array}$ & 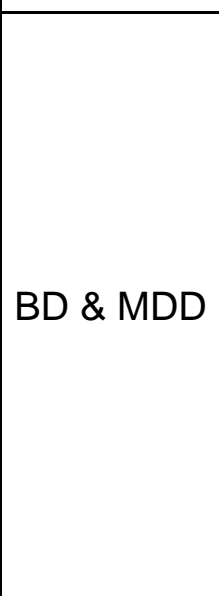 & $\begin{array}{l}\text { Total } \mathrm{N} \\
=5,692, \text { aged } \\
>18 \\
\mathrm{~N} \\
=3,711 \text { partici } \\
\text { pants with no } \\
\text { mood or } \\
\text { anxiety } \\
\text { disorder }\end{array}$ & $\begin{array}{l}\text { Sleep: series of } \\
\text { self-report } \\
\text { questions } \\
\text { Cognition: items } \\
\text { from WHO-DAS } \\
\text { pertaining to } \\
\text { cognition }\end{array}$ & $\begin{array}{l}\text { Participants with a mood disorder and any insomnia } \\
\text { symptom in the past year had significantly greater } \\
\text { 30-day cognitive impairment than participants with a } \\
\text { mood disorder and no insomnia symptoms in the } \\
\text { past year }(p=0.004) \text {. }\end{array}$ & $\begin{array}{l}\text { Subjective } \\
\text { measures of sleep } \\
\text { and cognition. }\end{array}$ \\
\hline
\end{tabular}




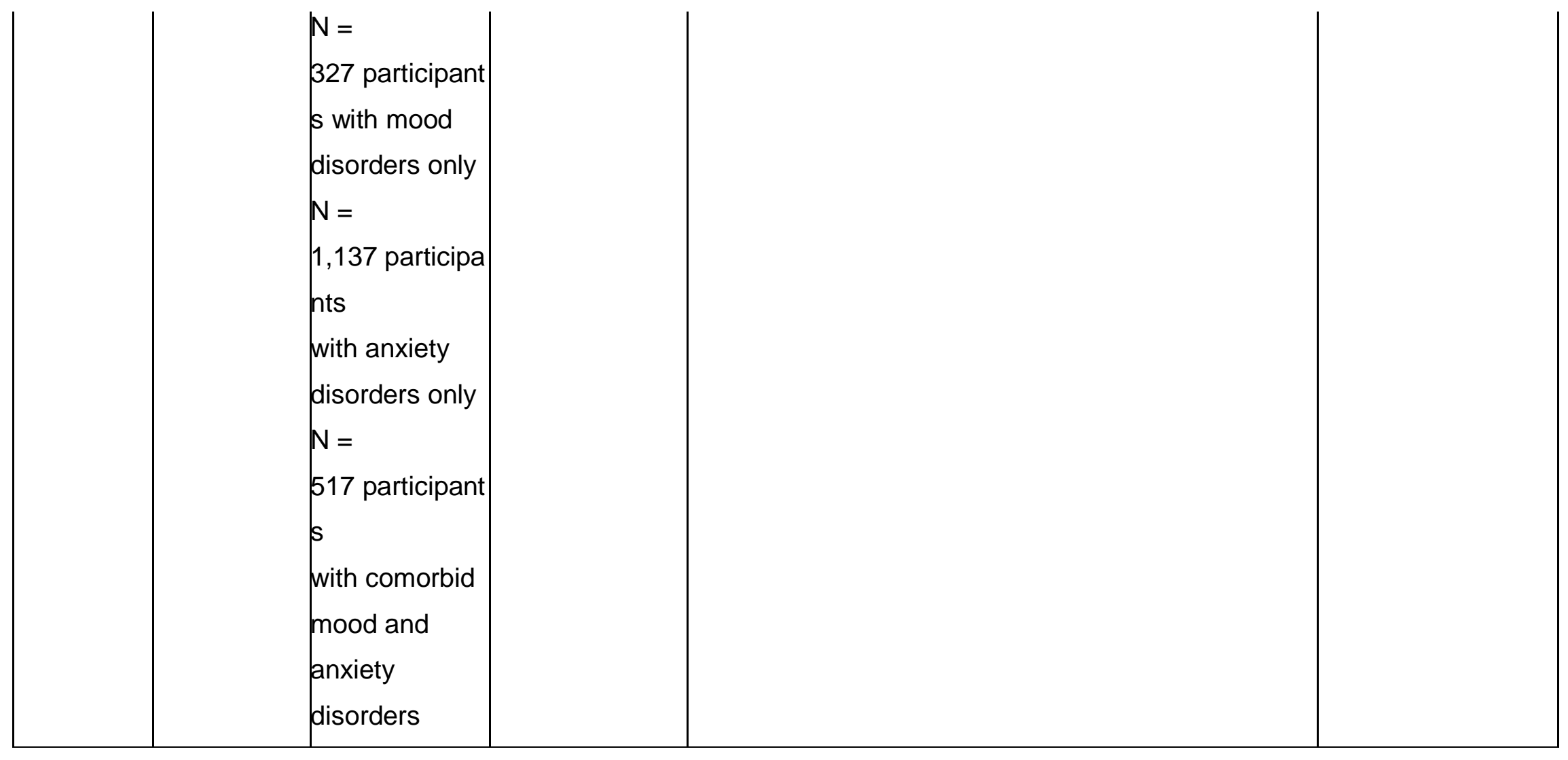

Abbreviations: TMT, Trail Making Test part A and B; CRT: Choice Reaction Time; DSST, Digit Symbol Substitution Test; PDQ-5-D, Perceived Deficits Questionnaire- 5-item for Depression; PSG, polysomnography; MCl, mild cognitive impairment; SQH, Sleep Quality in Hospital settings in German language ${ }^{61}$; PSQI, Pittsburgh Sleep Quality Index ${ }^{48}$; WTAR, Wechsler Test of Adult Reading ${ }^{62}$; WMS-III, Wechsler Memory Scale-III63; MCCB, MATRICS Consensus Cognitive Battery ${ }^{49}$; ISI, Insomnia Severity Index ${ }^{64}$; DSISD, Duke Structured Interview for Sleep Disorder ${ }^{16}$; IDS-C, Inventory of Depressive Symptoms - Clinician rated scale $^{65}$; SADS-C, Schedule for Affective Disorders and Schizophrenia-Change ${ }^{66}$; MADRS, Montgomery-Asperg Depression Ratings Scale ${ }^{67}$; UCII, Unstructured Clinical Interview for Insomnia; KBIT-II, Kauffman Brief Intelligence Test Second Edition ${ }^{68}$; 
DKEFS, Delis-Kaplan Executive Functioning System ${ }^{69}$; TOL, Tower of London ${ }^{70}$; CVLT, California Verbal Learning Test ${ }^{71}$; CVLT-II, California Verbal Learning Test Second Edition ${ }^{72}$; NART, National Adult Reading Test ${ }^{73}$; PVT, Psychomotor vigilance Test ${ }^{74}$; ANT, Attention Network Test ${ }^{75}$; DSST, Digit Symbol Substitution Test ${ }^{63}$; NSMT, Newcastle Spatial Memory Task ${ }^{76}$; VAS, visual analogic scale $^{77}$; FAST, Functioning Assessment Short Test ${ }^{60}$; STAN, South Texas Assessment of Neurocognition ${ }^{79}$; TAP, Test battery of Attentional Performance ${ }^{80}$; RWT, Regensburger Wortflüssigkeits Test ${ }^{81}$; ESS, Epworth Sleepiness Scale ${ }^{82}$; WHO-DAS, World Health Organization Disability Assessment Schedule-II. 


\section{Supplementary Tables}

Supplementary Table 1: Methodological evaluation of studies using the EPHPP Quality Assessment Tool for Quantitative Studies

\begin{tabular}{|c|c|c|c|c|c|c|c|c|}
\hline Author and year & $\begin{array}{c}\text { Mood } \\
\text { disorder(s) } \\
\text { studied }\end{array}$ & $\begin{array}{l}\text { Selection } \\
\text { bias }\end{array}$ & $\begin{array}{l}\text { Study } \\
\text { design }\end{array}$ & Confounders & Blinding & $\begin{array}{c}\text { Data } \\
\text { collection } \\
\text { method }\end{array}$ & $\begin{array}{c}\text { Withdrawals } \\
\text { and } \\
\text { dropouts }\end{array}$ & $\begin{array}{l}\text { Global } \\
\text { rating }\end{array}$ \\
\hline $\begin{array}{l}\text { Soehner and } \\
\text { Harvey, } 2012\end{array}$ & $\begin{array}{l}\text { MDD and } \\
\text { BD }\end{array}$ & Moderate & Weak & Strong & Moderate & Moderate & $\mathrm{N} / \mathrm{A}$ & Moderate \\
\hline Cabanel et al., 2019 & MDD & Moderate & Weak & Strong & Moderate & Strong & $\mathrm{N} / \mathrm{A}$ & Moderate \\
\hline Cha et al., 2019 & MDD & Moderate & Weak & Strong & Moderate & Strong & Strong & Moderate \\
\hline Muller et al., 2017 & MDD & Moderate & Weak & Strong & Moderate & Weak & $\mathrm{N} / \mathrm{A}$ & Weak \\
\hline Peng et al., 2018 & MDD & Moderate & Weak & Strong & Moderate & Strong & $\mathrm{N} / \mathrm{A}$ & Moderate \\
\hline $\begin{array}{l}\text { Wilckens et al., } \\
2020\end{array}$ & MDD & Moderate & Weak & Strong & Moderate & Strong & $\mathrm{N} / \mathrm{A}$ & Moderate \\
\hline Boland et al., 2015 & $\mathrm{BD}$ & Moderate & Moderate & Strong & Strong & Strong & Weak & Moderate \\
\hline Bradley et al., 2020 & BD & Strong & Moderate & Strong & Moderate & Strong & Strong & Strong \\
\hline Kanady et al., 2017 & BD & Moderate & Strong & Strong & Moderate & Strong & Strong & Strong \\
\hline $\begin{array}{l}\text { Laskemoen et al., } \\
2020\end{array}$ & BD & Strong & Weak & Strong & Moderate & Moderate & $\mathrm{N} / \mathrm{A}$ & Moderate \\
\hline Russo et al., 2015 & $\mathrm{BD}$ & Moderate & Weak & Moderate & Moderate & Strong & $\mathrm{N} / \mathrm{A}$ & Moderate \\
\hline Samalin et al., 2017 & BD & Strong & Weak & Weak & Moderate & Strong & $\mathrm{N} / \mathrm{A}$ & Weak \\
\hline Samalin et al., 2016 & $\mathrm{BD}$ & Strong & Weak & Weak & Moderate & Strong & N/A & Weak \\
\hline
\end{tabular}


medRxiv preprint doi: https://doi.org/10.1101/2021.08.12.21261470; this version posted August 13, 2021. The copyright holder for this preprint (which was not certified by peer review) is the author/funder, who has granted medRxiv a license to display the preprint in perpetuity. All rights reserved. No reuse allowed without permission.

\section{Identification of studies via databases and registers}

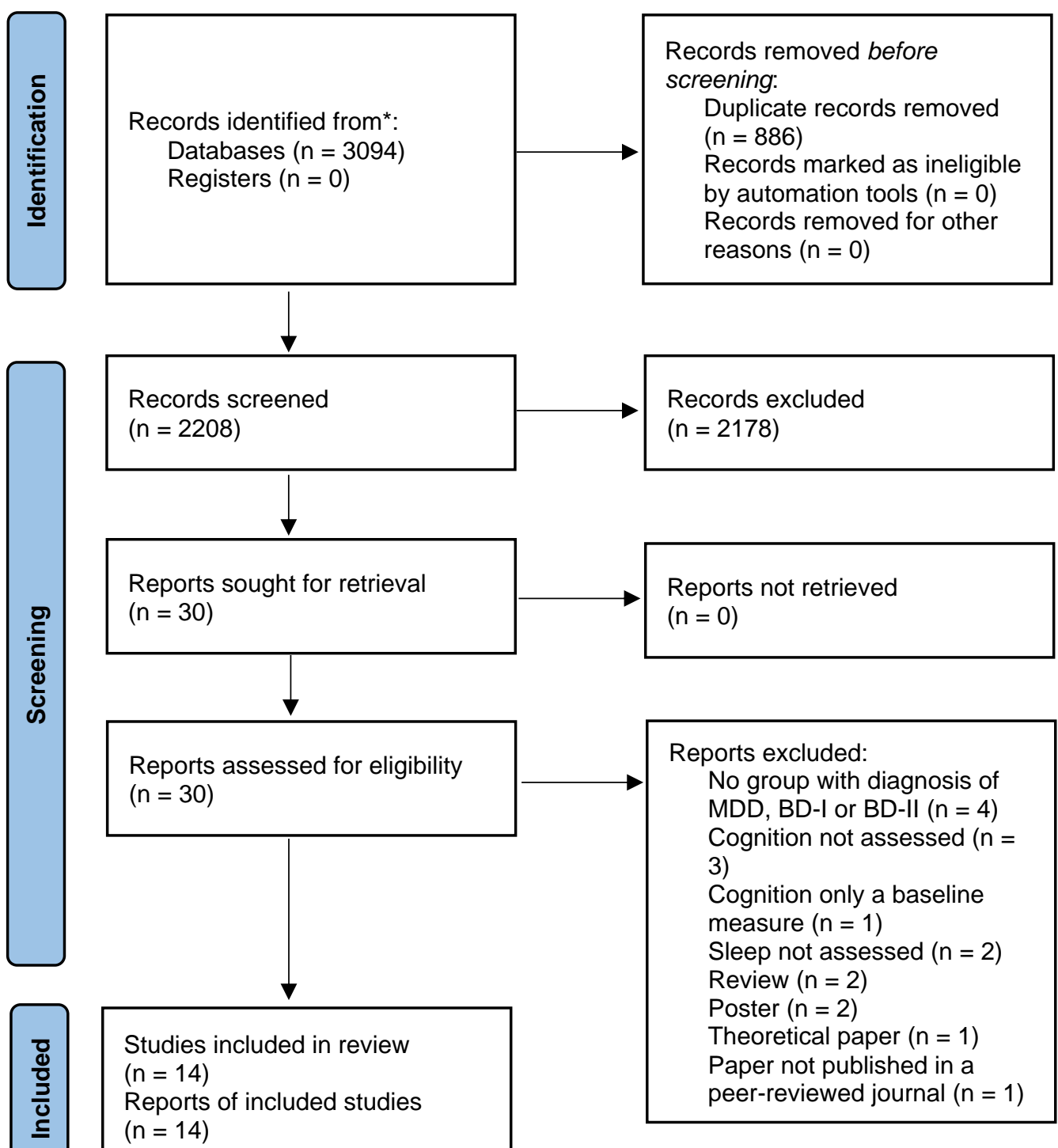

Figure 1. PRISMA 2020 Flow Diagram of study selection process 